\title{
Shell disease of rock oyster Crassostrea cucullata
}

\author{
Chandralata Raghukumar ${ }^{1}$, Vijay Lande ${ }^{2}$ \\ ' Biological Oceanography Division, National Institute of Oceanography, Dona Paula, Goa 403 004, India \\ ${ }^{2}$ Central Institute of Fisheries Education, Versova, Bombay 400061 , India
}

\begin{abstract}
A shell disease of Crassostrea cucullata Born. (rock oyster), caused by the fungus Ostracoblabe implexa Bornet et Flahault, is reported from Indian waters for the first time. The fungus causes small dark flecks on the inner surface of the valves. Decalcification of shells revealed that the fungal hyphae grew within the shell matrix. The fungus was cultured in yeast extract peptone seawater medium. Experimental infection of oyster shells in the laboratory was achieved by incubating the valves with fungal mycelia in seawater. Uninfected pieces of shell, placed in direct contact with infected oyster shells, became infected within $2 \mathrm{wk}$
\end{abstract}

\section{INTRODUCTION}

Fungi are important causal agents of 'shell diseases' in marine bivalves (Kinne 1983). They also play an important role in biodegradation of calcareous substrates including animal shells (Johnson \& Sparrow 1961. Höhnk 1969). These shell-boring fungi grow in shells of dead as well as living bivalves and derive nutrients from the organic matrix of the shell. The shell matrix is composed of the horny protein, conchiolin (Kinne 1983). Ostracoblabe implexa Bornet et Flahault is a fungus of uncertain taxonomic position (Alderman 1982), which causes serious shell disease in Ostrea edulis L. (the European flat oyster) and also infects the shells of Crassostrea angulata Lmk. in Western European waters (Alderman 1976). A shell disease of $C$. gryphoides from Bombay was reported but the causal agent was not described (Durve \& Bal 1960).
This work was initiated to determine the presence of shell boring fungi and cyanobacteria as disease causing agents and agents of biodegradation of the shells of various marine invertebrates.

\section{MATERIAL AND METHODS}

Shells were collected from various beaches of Goa, India $\left(15^{\circ} 27^{\prime}\right.$ to $15^{\circ} 38^{\prime} \mathrm{N}$ and $73^{\circ} 42^{\prime}$ to $\left.73^{\circ} 50^{\prime} \mathrm{E}\right)$ as indicated in Table 1 . Rock oyster Crassostrea cucullata and barnacle Balanus balanoides shells (dead and live) attached to intertidal rocks were removed, while the common whelk Turritella turitella (dead and live) and windowpane oyster Placuna placenta shells (dead) were collected from intertidal regions.

The valves from dead animals were washed thoroughly with seawater immediately after collection and stored at $15^{\circ} \mathrm{C}$. Shells of live rock oysters, common

Table 1. Invertebrate shells collected from Goan beaches and examined for the presence of shell-boring fungi

\begin{tabular}{|lllll|}
\hline Species & Class & Status & Lacation & Habitat \\
\hline $\begin{array}{l}\text { Common whelk Turritella } \\
\text { turritella Born. }\end{array}$ & Gastropoda & Live and dead & Caranzalem beach & Intertidal zone \\
$\begin{array}{l}\text { Rock oyster Crassostrea } \\
\text { cucullata Born. }\end{array}$ & Bivalvia & Live and dead & Anjuna, Baga and & Rocks in the intertidal \\
$\begin{array}{l}\text { Barnacle Balanus balanoides (L.) } \\
\begin{array}{l}\text { Windowpane oyster } \\
\text { Placuna placenta(L.) }\end{array}\end{array}$ & Crustacea & Live and dead & Anjuna beach & Intertidal rocks \\
\hline
\end{tabular}


whelk and barnacles were washed thoroughly with seawater, surface-sterilized and treated as below after removal of the soft tissues. Small pieces of shell were decalcified in $5 \%$ EDTA Na (ethylene diamine tetraacetic acid, disodium salt) solution for 2 to $4 \mathrm{~h}$. Following decalcification they were washed with seawater, surface-sterilized using $0.5 \%$ sodium hypochlorite (prepared in seawater) for $30 \mathrm{~s}$, and repeatedly washed with sterile seawater. These pieces were incubated in either (1) seawater containing streptomycin $(2.5 \mathrm{mg}$ $\mathrm{ml}^{-1}$ ) and penicillin (200 units $\mathrm{ml}^{-1}$ ) or (2) yeast extract peptone medium containing streptomycin and penicillin. Fungus which grew out of these pieces was subcultured and maintained in the yeast extract peptone medium (Alderman 1976).

In order to investigate the induction of zoospore production in the fungus, various nutrients at the following final concentrations were added to the yeast extract peptone medium: Tween 80 , a fatty acid ester $(1 \%)$, cholesterol, a sterol $(0.01 \%)$ and lecithin, a phospholipid $(0.01 \%)$. Stock solutions of cholesterol and lecithin were prepared in ethanol in such a way that $0.1 \mathrm{ml}$ of these solutions when added to $100 \mathrm{ml}$ of the medium yielded the final concentrations mentioned above. Tween 80 was sterilized separately and $1 \mathrm{ml}$ was added aseptically to $100 \mathrm{ml}$ medium (1\%). Triplicate flasks were inoculated with mycelial suspension and the cultures were examined for zoospore production. Growth was estimated gravimetrically by filtering the flask contents on the 14th day of culture on preweighed Whatman No. 1 filter paper. The mat was dried to constant weight at $40{ }^{\circ} \mathrm{C}$.

\section{RESULTS}

On incubation of shell pieces of the various invertebrates in different media, fungus grew only from shells of the rock oyster. Eighteen of 20 shells from Anjuna beach collected during February 1986 showed fungal growth when placed in yeast extract peptone medium, while only 5 of 20 shells each from Baga and Caranzalem beaches did so. The fungus was in all cases of one morphological type.

Rock oyster shells showing fungal growth had small black flecks and raised white nodules (Figs. 1 and 2) on the inner surface. Only the shells from live rock oyster showed these signs. Decalcification of such heavily infected portions revealed the presence of fungal mycelium having thin hyphae (Figs. 3 and 4). This fungus was morphologically similar to that which emerged from the shells on incubation in yeast extract peptone medium (Fig 5).

The fungus growth was visible as a web of hyaline mycelium, emerging from decalcified shells of rock oyster (Fig. 5) $7 \mathrm{~d}$ after incubation. The fungal mycelium was aseptate, thin ( 3 to $5 \mu \mathrm{m}$ in diameter), straight and bore enlargements, 12 to $15 \mu \mathrm{m}$ in diameter (Figs. 4 to 7 ), at regular intervals. Septa were visible in senescent mycelium. Based on these characters the fungus has been identified as Ostracoblabe implexa as described by earlier workers (Alderman \& Jones 1967). The enlargements were termed 'prochlamydospores'.

The fungus could easily be cultured in yeast extract peptone medium withour agar (Fig. 6). In solid medium with agar, growth was extremely slow.

Sporulation of the fungus could not be induced in the presence of cholestrol, lecithin or Tween 80 . Increased mycelial weight at the end of 2 wk was observed in the presence of lecithin and cholesterol (Table 2). Formation of prochlamydospores was also more frequent in this treatment (FIg. 7).

When isolated windowpane oyster and rock oyster shells were incubated in seawater with the pure culture of Ostracoblabe implexa, the fungus penetrated the shells and was seen to grow over the entire shell $2 \mathrm{wk}$ after incubation. Healthy pieces of shell placed on infected oyster shells were invaded by the fungus within $2 \mathrm{wk}$. Production of nodules was not observed in this set of laboratory experiments. On decalcification of the upper layer of these shells, the fungus was still found to be present.

When the infected and healthy shells were kept apart but in the same Petri dish containing seawater, no penetration of healthy shell was observed in $2 \mathrm{wk}$ of incubation. Only direct contact in the form of fungal mycelium from culture or infected piece of shell placed directly over the healthy shell piece resulted in successful penetration of healthy shells by the fungus.

Table 2. Ostracoblabe implexa. Growth in liquid yeast extract peptone medium with addtional nutrient growth factors

\begin{tabular}{|c|c|c|}
\hline Treatment & $\begin{array}{l}\text { Dry wt (mg } \\
50 \mathrm{ml}^{-1} \text { medium) }\end{array}$ & $\begin{array}{l}\text { Induction of pro- } \\
\text { chlamydospores }\end{array}$ \\
\hline $\begin{array}{l}\text { Yeast extract pep- } \\
\text { tone medium (con- } \\
\text { trol) }\end{array}$ & 5.8 & ++ \\
\hline $\begin{array}{l}\text { Yeast extract pep- } \\
\text { tone medium }+ \\
\text { Tween } 80\end{array}$ & 1.4 & + \\
\hline $\begin{array}{l}\text { Yeast extract pep- } \\
\text { tone medium }+ \\
\text { cholesterol }\end{array}$ & 7.9 & +++ \\
\hline $\begin{array}{l}\text { Yeast extract pep- } \\
\text { tone medium }+\end{array}$ & 8.0 & +++ \\
\hline \multicolumn{3}{|l|}{ lecithin } \\
\hline \multicolumn{3}{|c|}{$\begin{array}{l}{ }^{b} \text { Prochlamydospore formation: }+ \text {, poor }_{i}++ \text {, good }_{i}+++ \text {, } \\
\text { very good }\end{array}$} \\
\hline
\end{tabular}


Figs. 1 to 4. Crassostrea cucullata infected with Ostracoblabe implexa. Fig. 1. Infected oyster shell showing dark coloured flecks (arrow). Fig. 2. Higher magnification of rectangle showing white nodules (W) and black flecks (arrow) $(\times 15)$. Fig. 3. Fungal mycelium (arrow) inside the shell $(\times 100)$. Fig. 4. Higher magnification of rectangle showing fungal mycelium with prochlamydospore (arrow) $(\times 5200)$
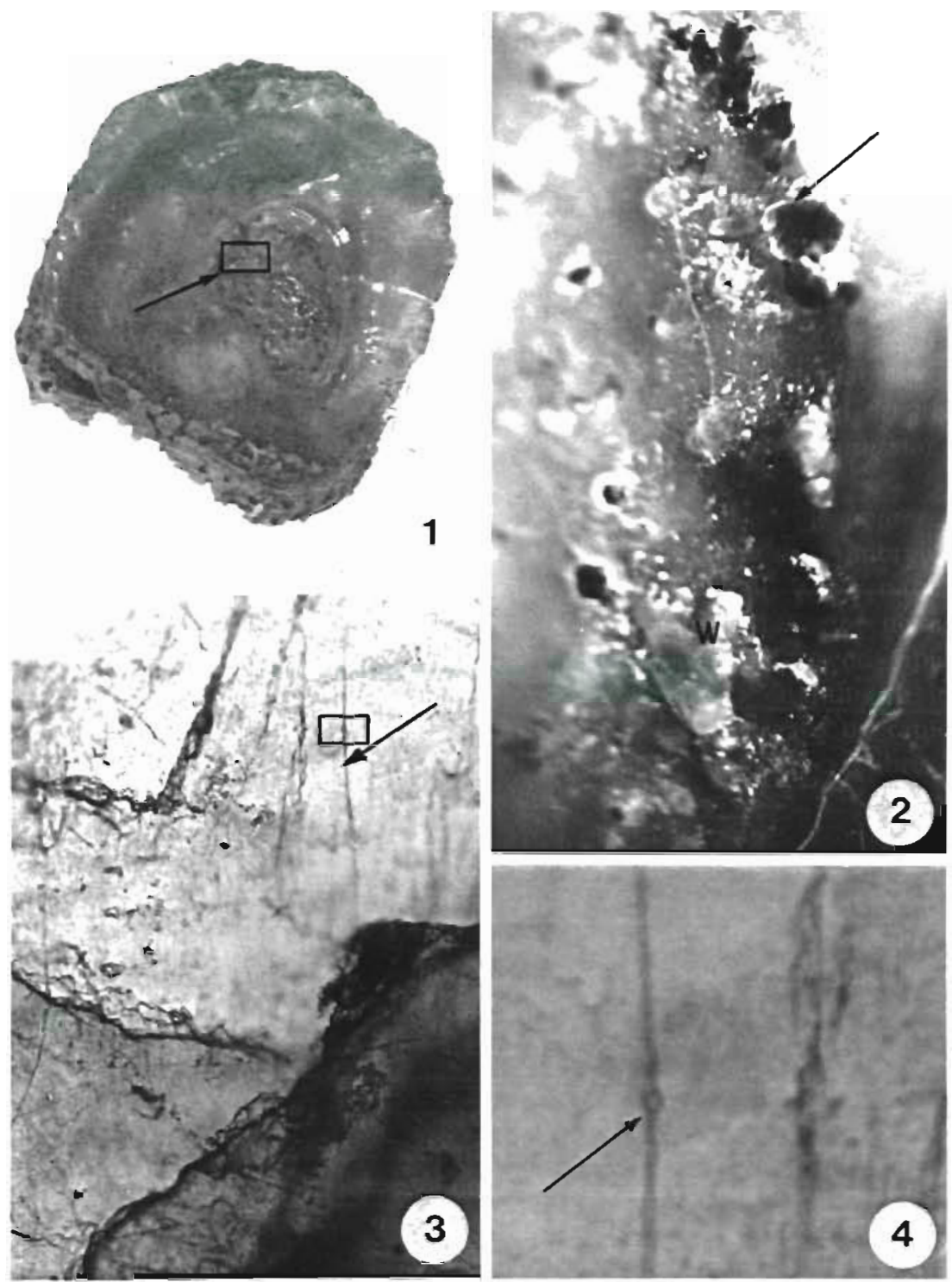

\section{DISCUSSION}

This report is the first documentation of shell disease of oysters in Indian waters. Ostracoblabe implexa had been reported to infect Crassostrea edulis and $C$. angulata by earlier workers, but infection of $C$. cucullata by $O$. implexa is being reported for the first time, thereby extending the known host range of this fungus. The specificity of the fungus to rock oyster shells cannot be explained at present. However, in the laboratory experiments it was also found to be growing in empty windowpane oyster shells.

The occurrence of heavy infection at Anjuna beach and comparatively low infection of oyster beds at other beaches also remains unexplained.

The experimental work suggests that for successful infection, direct contract with the fungus or infected shell material is necessary. As rock oysters always occur in clusters, mass infection of oyster beds solely by this method is possible. An even more rapid spread of disease might occur through reproductive propagules. However, the fungus was not observed to sporulate in the laboratory or in nature by earlier workers and in the present study.

Alderman (1982) reported that the fungus is initially confined to the shell but when it grows between living mantle tissue and the shell it sets up an irritation resulting in increased production of warts on the inner surface of the shell. This results in a reduced condition index of the oysters. As new oyster larvae settle on the shells of dead oysters, there is a risk of larvae also becoming infected. 

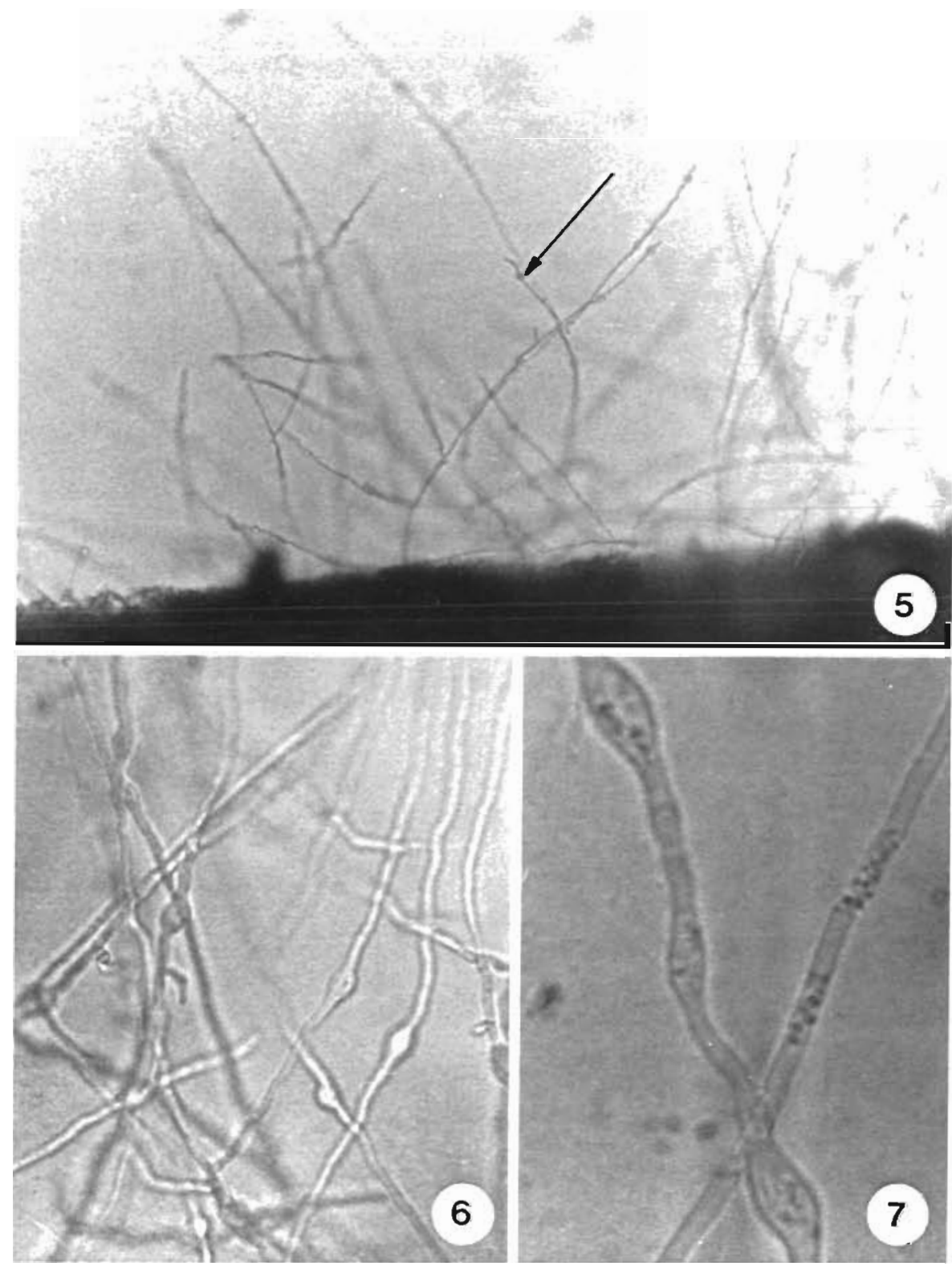

Figs. 5 to 7 . Ostracoblabe implexa. Fig. 5. Emergence from infected shell on incubation in seawater. Note the prochlamydospores (arrow) $(\times 100)$. Fig. 6. O. implexa growing in the yeast extract peptone medium $(\times 500)$. Fig. 7.0 implexa growing in the yeast extract peptone medium with added lecithin $(\times 1200)$
Heavy infection of oysters at temperatures above $20^{\circ} \mathrm{C}$ lasting for 2 or more wh has been reported (Alderman \& Jones 1971 a). Alderman \& Jones (1971b) reported $30^{\circ} \mathrm{C}$ to be optimum for growth of this fungus in the laboratory. In India, where water temperatures are always between 25 and $30^{\circ} \mathrm{C}$, this fungus may pose a serious threat to oyster beds.

Lecithin and cholesterol promoted growth of this fungus enormously in culture. Growth-promoting activity of these compounds on another disease-causing marine fungus (a parasite of marine crustaceans), Haliphthoros milfordensis, has also been reported (Bahnweg 1980).

Besides being a disease-causing agent, Ostracoblabe implexa, may play an important role in the biodegradation of calcareous substrates. Some of the shell-boring cyanobacteria have been shown to actively degrade windowpane oyster shells (Raghukumar et al. 1988). The cyanobacterial infested shells became brittle, fragile and lost weight (Plaziat 1984).

Acknowledgements. We thank the Director of the National Institute of Oceanography, Dr B. N. Desai, for support, the head of the Biological Oceanography Division, Dr A. H. Parulekar, for providing facilities and Dr S. Raghukumar for critically reading the manuscript.

\section{LITERATURE CITED}

Alderman, D. J. (1976). Fungal diseases of marine animals. In: Jones, E. B. G. (ed.) Recent advances in aquatic mycology. Elek Science, London, p. 223-260 
Alderman, D. J. (1982). Fungal diseases of aquatic animals. In Roberts, R. J. (ed.) Microbial diseases of fish. Academic Press, London, p. 189-202

Alderman, D. J., Jones, E. B. G. (1967). Shell disease of Ostrea edulis L. Nature, Lond. 216: 797-798

Alderman, D. J., Jones, E. B. G. (1971a). Shell disease of oysters. Fishery Invest., Lond. Ser. II 26: 1-18

Alderman, D. J., Jones, E. B. G. (1971b). Physiological requirements of two marine phycomycetes, Althornia crouchii and Ostracoblabe implexa. Trans. Br. mycol. Soc. 57: 213-225

Bahnweg, G. (1980). Phospholipid and steroid requirements of Haliphthoros milfordensis, a parasite of marine crustaceans, and Phytophthora epistomium, a facultative parasite of marine fungi. Botanica mar. 33: 209-218

Durve, V S., Bal, D. V (1960). Shell disease in Crassostrea gryphoides (Schlotheim). Curr. Sci. 29: 489-490
Höhnk, W. (1969). Über den pilzlichen Befall kalkiger Hartteile von Meerestieren. Ber. dt. wiss. Kommn Meeresforsch. 20: 129-140

Johnson, T. W., Sparrow, F. K. (1961). Fungi in oceans and estuaries. J. Cramer, Weinheim

Kinne, O. (ed.) (1983). Diseases of marine animals, Vol. II. Biologische Anstalt Helgoland, Hamburg

Plaziat, J. C. (1984). Mollusk distribution in the Mangal. In: Por, F. D., Dor, I. (eds.) Hydrobiology of the Mangal. Junk Publishers, The Hague, p. 111-143

Raghukumar, C., Pathak, S., Chandramohan, D. (1988). Biodegradation of calcareous shells of the windowpane oyster by shell boring cyanobacteria. In: Proceedings of International Conference on Marine Biodeterioration, Goa, 16-20 Jan 1986 (in press) 